\title{
МІЖНАРОДНИЙ КРУГЛИЙ СТІЛ «РОЗВИТОК ПСИХОЛОГІЇ В УКРАЇНІ ТА ПОЛЬЩ॥ (ДО 30-РІЧЧЯ НЕЗАЛЕЖНОСТІ УКРАЇНИ»)
}

https://doi.org/10.37472/2707-305X-2021-3-2-17-10

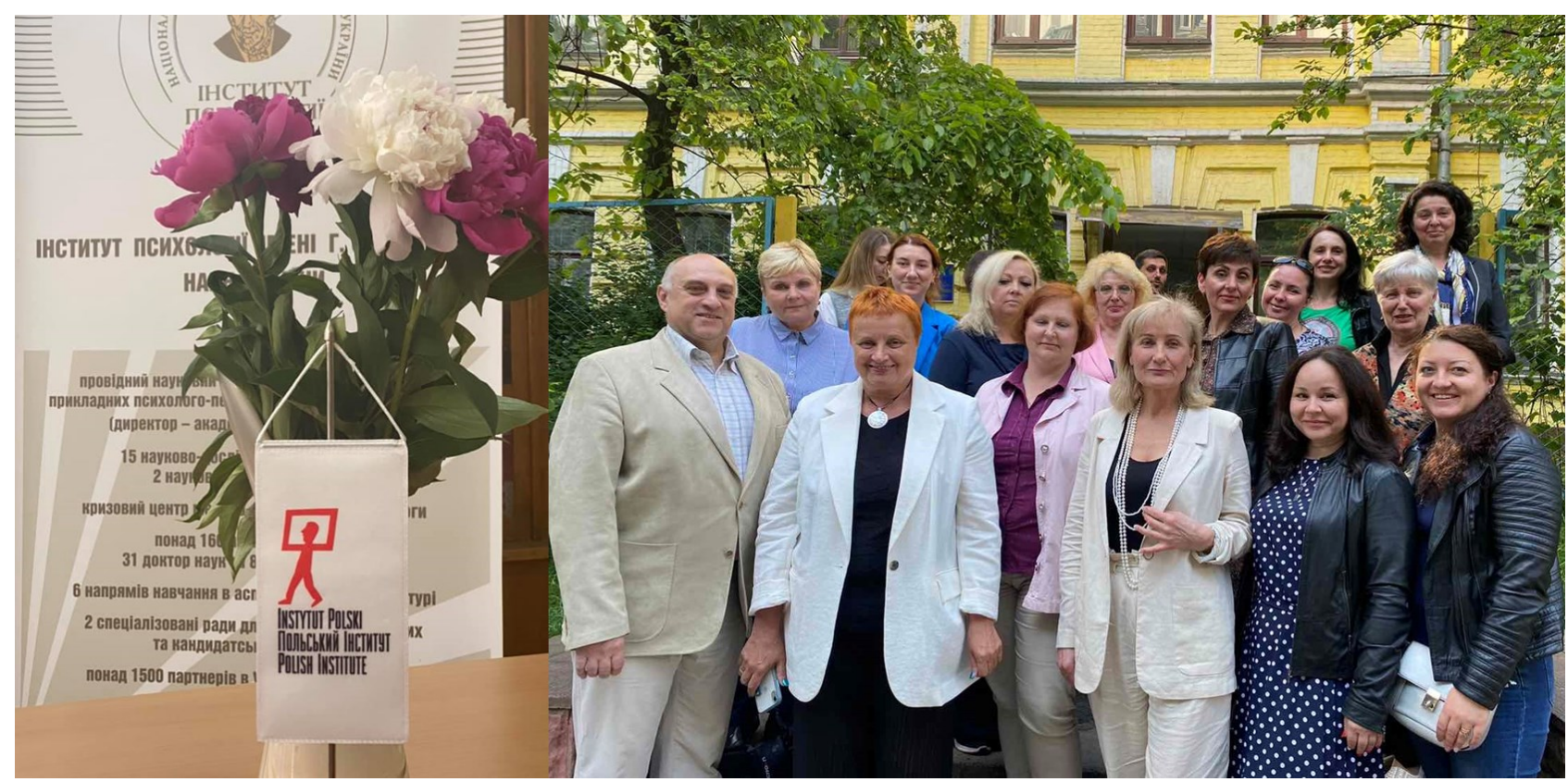

\section{МАКСИМЕНКО Сергій Дмитрович}

доктор психологічних наук, професор, дійсний член (академік) НАПН України, академік-секретар відділення психології, вікової фізіології та десректології Начіональної академії педагогічних наук України; директор Інституту психології імені Г.С. Костюка Національної академії педагогічних наук України, м. Київ, Україна

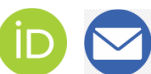

КАРАМУШКА Людмила Миколаївна доктор психологічних наук, професор, дійсний член (академік) НАПН України, заступник директора з науково-організаційної роботи та міжнародних наукових зв'язків Інституту психології імені Г.С. Костюка Національної академії педагогічних наук України, м. Київ, Україна

Анотація. У статmі представлено результати проведення Міжнародного круглого столу «Розвиток психології в Україні та Польщі (до 30-річчя Незалежності України)», який відбувся 7 червня 2021 р. у м. Києві, в Інституті психології імені Г.С. Костюка Національної академії педагогічних наук України. Круглий стіл проведено в рамках заходів НАПН України з відзначення 30-ї річнищі Незалежності України. Відображено актуальні психологічні проблеми, що їх досліджують польські та українські вчені, і які стосуються психологічних аспектів життєдіяльності сучасного суспільства, освітніх та інших організацій, особистості. Визначено перспективи взаємодії українських та польських психологів у вирішенні актуальних проблем сьогодення, зокрема, пов'язаних з пандемією COVID-19.

Ключові слова: психологія; розвиток психології; співпраця України та Польщі в галузі психології.

Одним із важливих напрямів діяльності інститутів Національної академії педагогічних наук України $€$ реалізація програми міжнародного співробітництва. У рамках цієї програми 7 червня 2021 р. в Інституті психології імені Г.С. Костюка
НАПН України відбувся міжнародний круглий стіл «Розвиток психології в Україні та Польщі (до 30річчя Незалежності України)».

Організаторами круглого столу виступили: Національна академія педагогічних наук України, 
Інститут психології імені Г.С. Костюка (лабораторія організаційної та соціальної психології), Польський інститут в Києві, Інформаційно-освітня платформа IEP FAMILIAE CIVITAS (м. Катовіце, Польща), ВГО «Товариство психологів України», Українська Асоціація організаційних психологів та психологів праці.

У роботі круглого столу взяли участь з польської сторони:

- Роберт Чижевський, директор Польського Інституту у Києві, радник Посольства Республіки Польща в Україні;

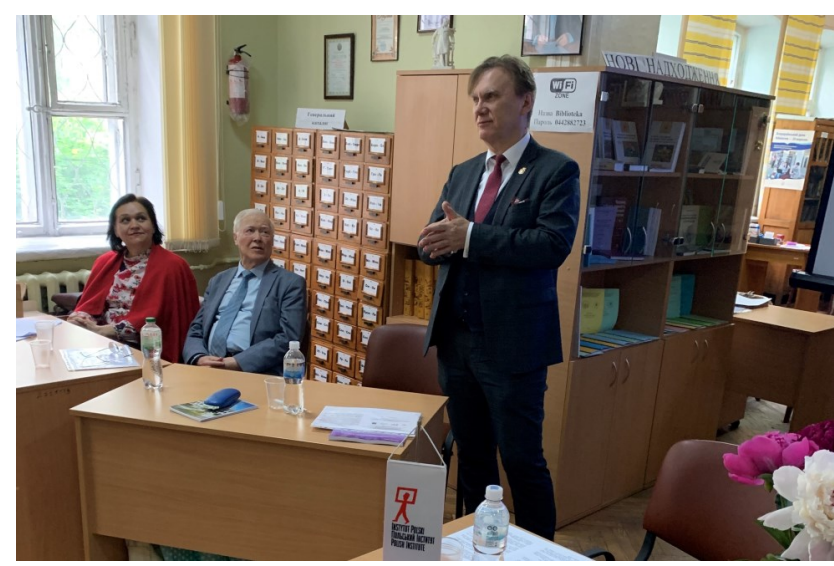

- Віктор Собіянський, експерт з програмної діяльності Польського Інституту у Києві;

- Мирослав Станішевський, доктор гуманістичних наук PhD, психолог, науковий експерт 3 напряму емоційно-стресової психотерапії, проблем стресу і міжособистісної залежності Інформаційно-освітньої платформи IEP FAMILIAE CIVITAS (м. Катовіце, Польща);

- Жанна Станішевська, доктор гуманістичних наук PhD, психолог, науковий експерт з напряму емоційно-стресової психотерапії, проблем стресу і міжособистісної залежності Інформаційноосвітньої платформи IEP FAMILIAE CIVITAS (м. Катовіце, Польща).

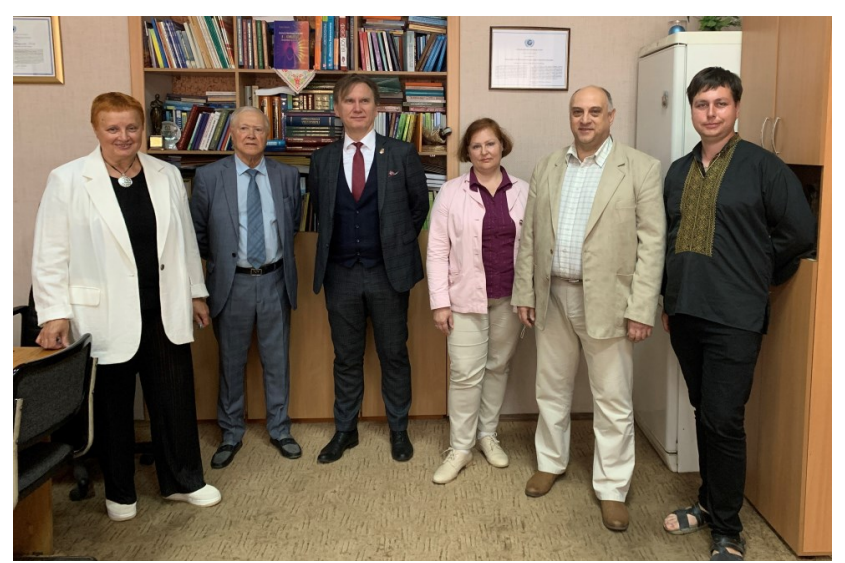

Українську сторону представляли:

- Сергій Максименко, академік НАПН України, директор Інституту психології імені Г.С. Костюка НАПН України;

- Людмила Карамушка, академік НАПН України, заступник директора з науково-організаційної роботи та міжнародних наукових зв'язків Інституту психології імені Г.С. Костюка НАПН України;

- співробітники, аспіранти й докторанти лабораторії організаційної та соціальної психології та інших підрозділів Інституту;

- представники наукових, освітніх та інших організацій (Державної установи «Національний антарктичний науковий центр» Міністерства освіти і науки України, загальноосвітньої школи № 274 з поглибленим вивченням англійської мови м. Києва, Запорізького національного університету, Київського інституту сучасної психології та психотерапії, Київського національного університету імені Тараса Шевченка, Кіровоградської обласної організації Товариства сприяння обороні України, комунального навчального закладу Київської обласної ради «Київський обласний інститут післядипломної освіти педагогічних кадрів», Миколаївського національного університету імені В.О. Сухомлинського, Сумського обласного інституту післядипломної педагогічної освіти, Чернівецького національного університету імені Юрія Федьковича, Управління освіти і науки Білоцерківської міської ради Київської області та ін.).

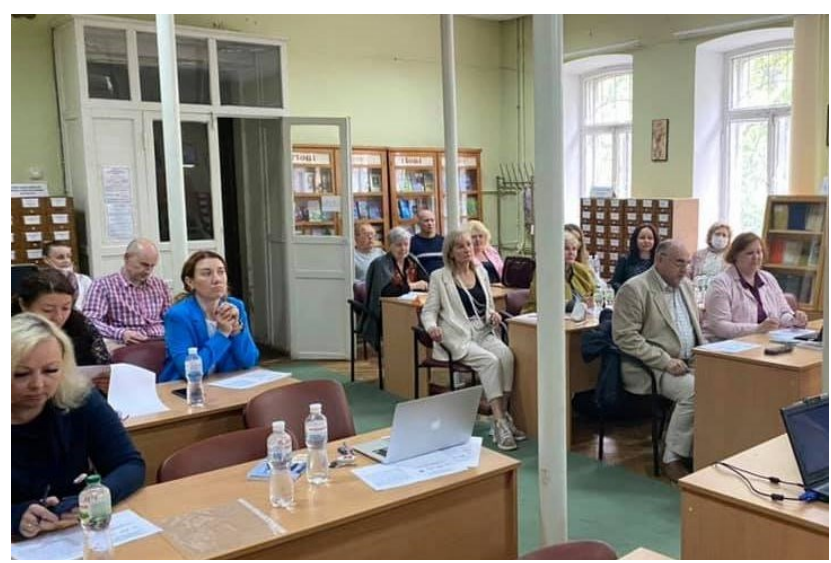

Усього у круглому столі взяли участь 35 науковців та освітян з різних міст України (Біла Церква, Запоріжжя, Київ, Кропивницький, Суми, Чернівці та ін.).

Обговорено низку актуальних психологічних проблем, що їх досліджують польські й українські вчені, і які стосуються психологічних аспектів життєдіяльності сучасного суспільства, освітніх та інших організацій, особистості. Представлені наукові 
презентації можна об'єднати в декілька основних смислових груп.

Перша група розробок стосується безпосередньо співпраці українських та польських вчених у галузі психології і знайшла відображення в таких виступах: «Співпраця українських і польських вчених в галузі суспільного здоров'я на прикладі емоційно-стресової психотерапії» (доктор гуманістичних наук PhD Мирослав Станішевський); «Перспективи побудови спільних наукових і навчальних програм в галузі психології, приклади успішних практик» (доктор гуманістичних наук PhD Жанна (танішевська); «Участь Миколаївського національного університету імені В.О. Сухомлинського в українсько-польських міжнародних наукових програмах» (кандидат психологічних наук, доцент Ірина Литвиненко).
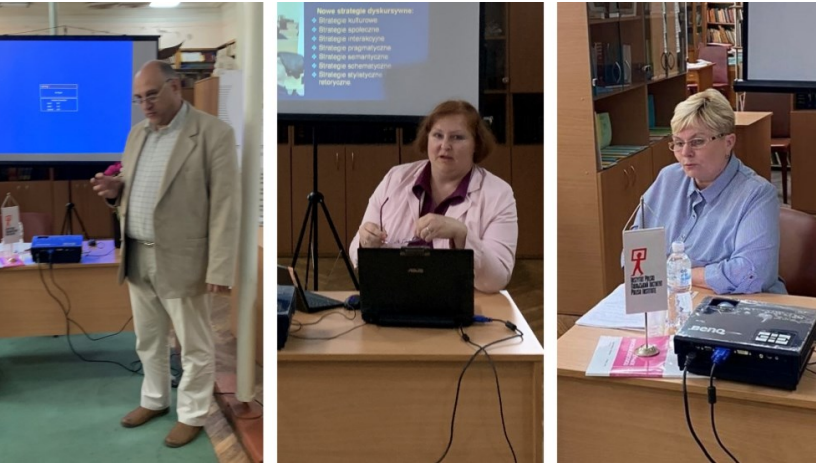

Друга група - розробки з проблем розвитку потенціалу особистості та ії життєстійкості, що представлені такими презентаціями: «Механізми розвитку психологічного потенціалу особистості» (академік НАПН України, доктор психологічних наук, професор Сергій Максименко); «Актуальні проблеми дискурсивного конструювання досвіду особистості» (академік НАПН України, доктор психологічних наук, професор Наталія Чепелєва); «Життєстійкість у психології: від загального до конкретного» (член-кореспондент НАПН України, доктор психологічних наук, професор Олег Кокун);

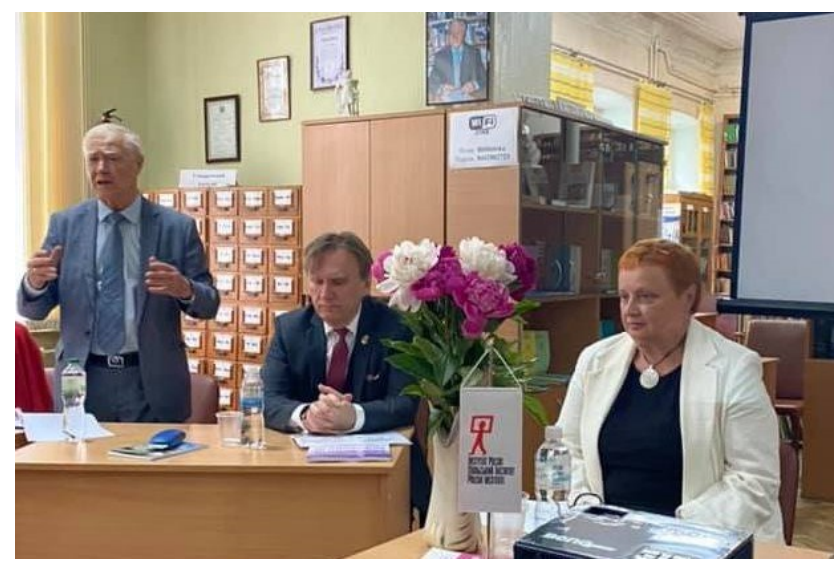

«Особистісні смисли у структурі інноваційного потенціалу українського вченого» (кандидат психологічних наук, доцент Галина Гуменюк).

Третю групу досліджень присвячено проблемам психологічного здоров'я та благополуччя особистості, зокрема: «Психологічне здоров'я персоналу освітніх організацій в умовах пандемії COVID-19: актуальні напрями дослідження» (академік НАПН України, доктор психологічних наук, професор Людмила Карамушка); «Особливості розвитку самоефективності персоналу освітніх організацій» (доктор психологічних наук Оксана Креденцер); «Внутрішній потенціал психологічного благополуччя особистості» (доктор психологічних наук, професор Людмила Сердюк); «Суб'єктивне благополуччя як індикатор психологічного здоров'я персоналу освітніх організацій» (доктор психологічних наук, професор Олена Бондарчук); «Психологічні особливості креативності як чинника психологічного здоров'я персоналу освітніх організацій» (кандидат психологічних наук Валентина Лагодзінська); «Забезпечення психологічного здоров'я менеджерів освітніх організацій» (кандидат психологічних наук Антоніна Шевченко); «Толерантність персоналу освітніх організацій в умовах суспільних викликів» (кандидат психологічних наук Кіра Терещенко).
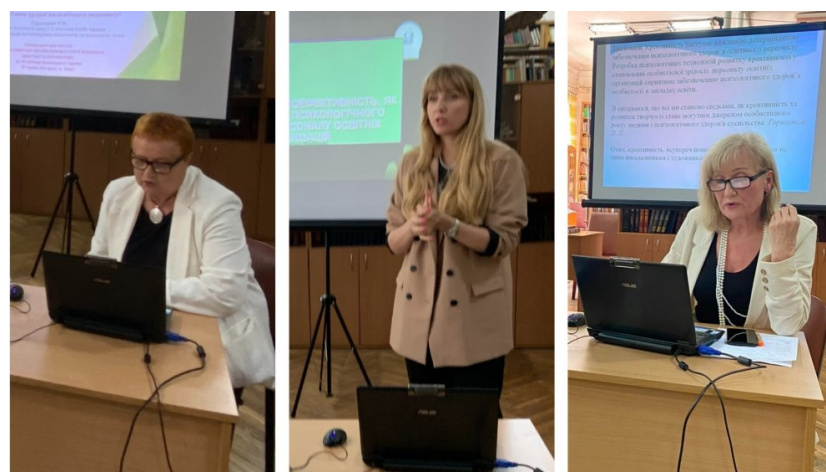

Четверmy групу представляли дослідження, які стосувалися психологічних особливостей економічної соціалізації дітей та молоді, формування економічної культури особистості, реалізації фінансових сценаріїв особистості. У цьому напрямі висвітлено такі розробки: «Особливості економічної соціалізації школярів з малозабезпечених сімей» (доктор психологічних наук Наталія Дембицька, кандидат психологічних наук Олена Новосядла); «Роль батьківської компетентності в становленні економічної культури дітей» (кандидат психологічних наук Тетяна Мельничук); «Особливості економічного самовизначення студентської молоді» (кандидат філософських 

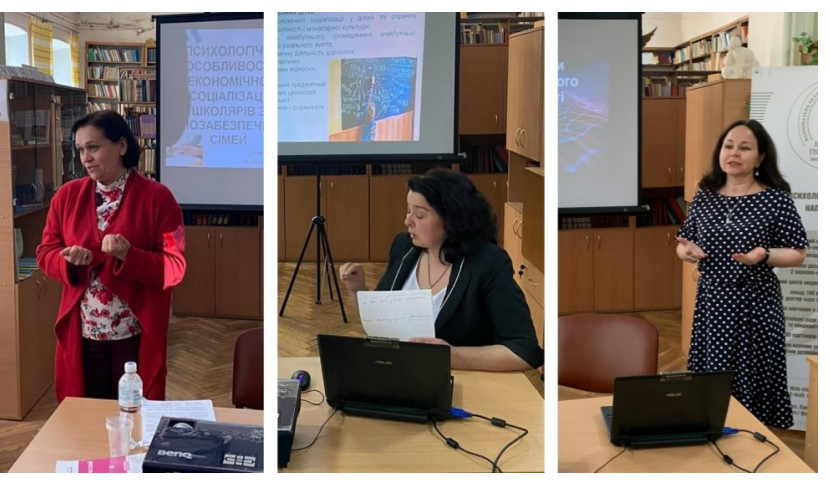

наук, доцент Ольга Лавренко); «Психологічні особливості монетарної соціалізації студентської молоді (кроскультурне дослідження) (кандидат психологічних наук Ірина зубіашвілі); «Психологічні чинники формування фінансового сценарію особистості» (Наталія Клименко).

До п’ятої групи віднесено розробки щодо психологічних особливостей управління організаціями в сучасних умовах та психологічних особливостей діяльності фахівців соціономічної сфери. Вони знайшли відображення в таких презентаціях: «Психолого-організаційні аспекти управління освітніми округами як інноваційними організаціями» (доктор психологічних наук, професор Алла Вознюк); «Фахівець із соціальної роботи: особистість, професіонал, людина» (доктор психологічних наук, професор Валентина Балахтар); «Особливості державно-громадського управління загальною середньою освітою в умовах децентралізації та автономії закладів освіти» (Юрій Петрик); «Модель підвищення ефективності управлінської діяльності менеджерів освітніх організацій» (кандидат педагогічних наук, доцент Алла Клочко); «Формування толерантного освітнього середовища закладу загальної середньої освіти» (кандидат психологічних наук Вікторія Баранова); «Соціально-психологічні умови розвитку соціального лідерства у студентів» (кандидат психологічних наук Тарас Карамушка); "Організаційно-психологічні чинники вибору копінгстратегій керівниками загальноосвітніх навчальних закладів» (Юлія Снігур); «Формування психологічної готовності до інноваційних змін у працівників музеїв» (Тетяна Цвілодуб); “Становище та розвиток сімейної медіації в Україні» (Тетяна Білик).

До шостої групи увійшли розробки про психологічні особливості діяльності особистості та команд в екстремальних умовах (зимівників в антарктичних експедиціях, парашутистів під час виконання складних професійних завдань тощо). 3-поміж них мали місце такі презентації: «Психологічні особливості міжособистісної взає-

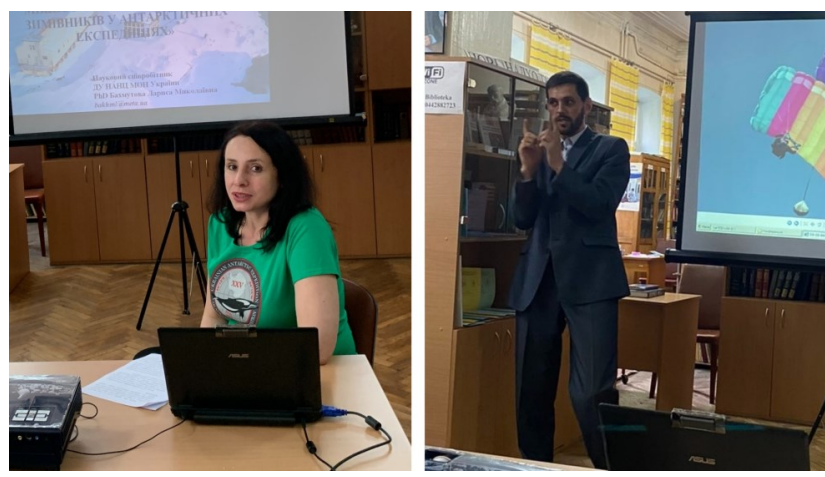

модії зимівників в антарктичних експедиція» (доктор філософії у галузі психології Лариса Бахмутова); “Соціально-психологічне забезпечення групової взаємодії як актуальний напрям кроскультурних досліджень» (на матеріалах купольної акробатики) (Олександр Пустовий).

Презентації викликали значний інтерес в учасників круглого столу та супроводжувалися жвавими дискусіями. Наголошено, що в українських та польських психологів є багато спільних підходів, які стосуються дослідження означених психологічних проблем. Разом з тим у кожної із сторін $є$ унікальні дослідження, які здійснюються та знаходять відображення в психологічній науці та практиці кожної з країн, відповідно до ії соціальнокультурних та освітніх традицій.

Окрім того, відбулася презентація нової книги польських дослідників «Емоціонально-стресова психотерапія. Міжособистісна комунікація» (М. Станішевський, Ж. Станішевська), яка була передана в наукову бібліотеку Інституту психології імені Г.С. Костюка НАПН України.

Круглий стіл сприяв обміну підходами польських та українських вчених до діагностики складних психологічних проблем сьогодення, зокрема, обумовлених пандемією COVID-19, та розроблення психологічних технологій щодо їх вирішення.

За результатами круглого столу прийнято рекомендації, в яких відображено перспективи взаємодії українських та польських психологів у вирішенні актуальних проблем сьогодення:

- участь у дослідженні психологічних проблем, які виникають в життєдіяльності особистості, організації та суспільства в умовах пандемії COVID-19;

- обмін діагностичним інструментарієм, спільне розроблення нових методик та їх апробація і валідизація;

- впровадження та обговорення спільних тренінгових програм та інших форм психологічної підтримки особистості, організації та суспільства (консультування, реабілітація, психотерапія тощо); 
- спільне розроблення та апробація навчальних програм для підготовки психологів та інших груп фахівців (менеджерів, педагогічних працівників, економістів, рятувальників тощо) в умовах університетської освіти;

- участь в опонуванні дисертаційних досліджень для отримання звання доктора філософії;

- розроблення спільних наукових та освітніх проєктів та їх реалізація за підтримки міжнародних організацій.

Дякуємо всім учасникам за участь в конференції та бажаємо нових, цікавих творчих ідей, проєктів та напрямів діяльності!

\section{СПИСОК ВИКОРИСТАНИХ ДЖЕРЕЛ}

Інститут психології імені Г.С. Костюка НАПН України.

(2021, 7 червня). Міжнародний круглий стіл «Розвиток психології в України та Польщі» (до 30- річчя Незалежності України). http://psychologynaes-ua.institute/read/2427/

Інститут психології імені Г.С. Костюка НАПН України. (2021, 7 червня). Програма міжнародного круглого столу "Розвиток психології в України та Польщі» (до 30-річчя Незалежності України). http:// psychology-naes-ua.institute/files/pdf/ program_poland-ukrainian_cooperation07.06_1623143624.pdf

Інститут психології імені Г.С. Костюка НАПН України. (2021, 8 червня). Одним із важливих напрямів діяльності інститутів Національної Академії педагогічних наук України є реалізація програми міжнародного співробітниитва [Допис]. Facebook. https://www.facebook.com/kostiuk.in.psy/ posts/3462207513882690

Українська Асоціація організаційних психологів та психологів праці. (2021, 7 червня). Міжнародний круглий стіл «Розвиток психології в України та Польщі (до 30-річчя Незалежності України). http:// uaoppp.com.ua/read/437/

\section{INTERNATIONAL ROUND TABLE "DEVELOPMENT OF PSYCHOLOGY IN UKRAINE AND POLAND (DEVOTED TO THE 30th ANNIVERSARY OF UKRAINE'S INDEPENDENCE)"}

\section{Serhii Maksymenko}

DSc in Psychology, Professor, Full Member (Academician) of NAES of Ukraine, Academician Secretary of the Division of Psychology, Age Physiology and Defectology, National Academy of Educational Sciences of Ukraine; Director,

G.S. Kostiuk Institute of Psychology of the National Academy of Educational Sciences of Ukraine, Kyiv, Ukraine Liudmyla Karamushka

DSc in Psychology, Professor, Full Member (Academician) of NAES of Ukraine, Deputy Director for research and organizational work and international scientific relations, G.S. Kostiuk Institute of Psychology of the National Academy of Educational Sciences of Ukraine, Kyiv, Ukraine

Abstract. The results of the International Round Table "Development of Psychology in Ukraine and Poland (devoted to the 30th anniversary of Ukraine's independence)", which took place on June 7, 2021, in Kyiv, at the G.S. Kostiuk Institute of Psychology of the National Academy of Educational Sciences of Ukraine, are presented. The round table was held as part of the NAES of Ukraine Action Plan to celebrate the 30th anniversary of Ukraine's independence. The actual psychological problems studied by Polish and Ukrainian researchers concerning the psychological aspects of modern society, education and other institutions, the individual are reflected. The prospects for further cooperation between Ukrainian and Polish psychologists in solving current problems, in particular, related to the COVID-19 pandemic, are identified.

Keywords: psychology; development of psychology; cooperation of Ukraine and Poland in the field of psychology.

Дата публікації: 30 вересня 2021 р. 